\title{
Religious Compulsion and Carnage: Contemporary Discourses in the Context of Middle East
}

\footnotetext{
Farooq Hassan ${ }^{1}$, Anwarullah Tayyabi ${ }^{2}$, Nasiruddin Siddiqui ${ }^{3}$

${ }^{1}$ Post doc. Georgetown University (USA), Associate Professor, Department of Humanities, NED

University of Engineering \& Technology Karachi Pakistan

${ }^{2}$ Assistant Professor, Institute of Health and Business management, Jinnah Sindh Medical

University, Karachi (Pakistan)

${ }^{3}$ Assistant Professor, Department of Islamic Learning, University of Karachi (Pakistan)

\begin{abstract}
A B S T R A C T
Why certain Islamic legal principles have been misinterpreted and also misunderstood by the Muslims and followers of other religions. When the Pope Benedict XVI spoke (in Germany, 2006) about the verse (Qur'an 2:26)"no compulsion in religion", which created havoc among the Muslims all over the world.

While discussing the reasoning in Islamic Jurisprudence, the concept of maqasid al-Sari'a of alSatibi's (d.1388 CE) has been quoted by Muslims so as to justify suicide bombing, forced conversion and to do away with hudud by liberals and to act in between two limits by moderates. Reports illustrate that the Islamic State (IS) is brutally killing and terrorizing religious minorities in their occupied territories. This paper indicates that IS stance is contradictory to much Islamic ideology, as the Qura'nic notion (9:119) of always telling the truth. Moreover, Muslim young blood was instigated to serve IS, without parents' consent, which is strictly forbidden.
\end{abstract}

Key words: No Religious compulsion; Contemporary Middle-East; Islamic legal heritage; varying interpretation
}

\section{Background of the Study}

Religion should be a source of personal solace, serenity and should help individuals and civilizations come to terms with themselves and be at peace with the world. At any cost, religion can't be used to justify terrorism and murder of innocents or to promote intolerance and bigotry. One of the ways to bring civilizations together is a rationalistic and realistic interpretation of Holy Scriptures. The Prophet Muhammad (PBUH) said that people who desire for Allah's intimacy should be noble, kind and loving with humanity in general, "All mankind is Allah's family; the best among you in the sight of Allah is he who is humane towards his family." "When the case of a Jew (or Christian) being killed by a Muslim was reported to the Messenger of Allah to which he responded, "I have more responsibility to protect the rights of people who came under my jurisdiction." 
Therefore, a Muslim was granted death sentenced for the murder of a person from ahl alktab. ${ }^{\text {ii }}$ The Prophet endorsed the biblical principle of blood for blood or life for life. The criminal irrespective of the religion he belongs to is to be punished. Imam Abu Yusuf (d. 182/797) said, " Umar (d.23/644) on his deathbed said, "I want to put this in my will to the next caliph of Muslims that the responsibility of the security of the lives, properties, and respect of non-Muslims, the Prophet (PBUH) had taken upon himself as his responsibilities, should be undertaken by you too. The promise and pacts made with them by the Prophet (PBUH) should be honored. They should not be overburdened with something which is not in their power.' ${ }^{\text {'iii }}$

It is the religious obligation of Muslim Ummah to set up a culture of mildness rather than that of extremism and terrorism.

While addressing his followers the Messenger of Allah (PBUH) admonished, "Behold! Every one of you is a shepherd and every one of you is responsible for his subjects. So the sultan who rules the people is a guard and responsible for his subjects. And the husband is the custodian of the members of the household and is responsible for his subjects. And the wife is the custodian of the house of her husband and of his children and is responsible for them. And the slave of a man is the custodian of the wealth of his master and is responsible for it. Beware! Every one of you is a shepherd and every one of you is responsible for his subjects." ${ }^{\text {iv }}$ This Prophetic statement indicates that each and every one will have to account for his duties in Akhirah. The higher the status of a person the greater are his obligations to establish peace and combat terrorism. Where do the extremists' like ISIS get the idea of Killing foreigners under treaty or those who have entered Muslim lands under the security of the Muslims, for no sin other than belonging to specific nationalities and its justification from? Although this act of barbarism is not allowed in Shari'a. ${ }^{v}$

\section{Post 9/11 Arguments against the Verse (2:256)}

Positive and negative remarks of spiritual Heads of religions have indelible effects on the followers of those religions. The misinterpretation of certain verses of the Qur'an by Western scholars has resulted in a lot of prejudice and hatred towards Islam 
and Muslims. The remarks in an address of Pope Benedict XVI on September 12th, 2006 at the University of Regensburg, Germany angered Muslims the world over. In his eightpage long address he devoted only four paragraph to Islam and too derogatory manner. He cited a remark made by a fourteenth-century Byzantine Emperor about Prophet Muhammad (PBUH) which said, "Show me just what Muhammad brought that was new, and there you will find things only evil and inhuman, such as the Command to spread by the sword the faith he preached. ${ }^{\prime \prime i}$ The Pope remarked that the Quranic passage, "There is no compulsion in religion" (2:256) was revealed to the Muhammad in his early year of Prophethood in Makkah, a time when Muhammad was powerless and under threat by enemies. The Pope also commented on this passage that in later years in Medina, when Muhammad had both strength and stability, he acted, contrary to what he had said earlier. Muslim scholars offered logical explanations based on the Qur'an and pointed to factual errors made by the Pope in his address. Muslim scholars also clarified the fact that this passage was a later revelation in contradiction to the Pope's comment that it was an early revelation. ${ }^{\text {vii }}$ The Pope may have tried to say that in some interpretations of Shari'a, this fact would imply that it does not prove the final verdict about Islamic duty, but only

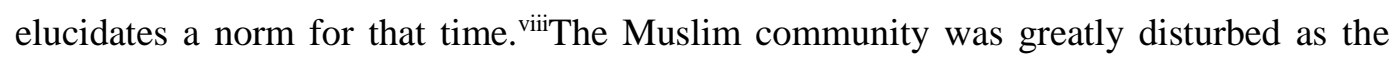
Pope with his lofty position wanted to denigrate Islam and the Muslim world. The Pope felt sorry that Muslim feelings were hurt but nothing was changed in the Pope's address.

Similar provocative remarks were made by Michael Evans in his book, "Beyond Iraq-The next move" in 2003. Evans convinced that "God demanded the invasion of Iraq." Far worse, Evans pleads for the invasion of other Islamic countries too, which will prove to be a spiritual battle between Christianity and enemy religion (Islam). Evans called Muslims, Satanic forces, and demons. Disregarding the verse of Qur'an (2:256) "there is no compulsion in religion" Evans accuses the Prophet of Islam of proto terrorism, who killed Jews only for not accepting Islam and not for any other reasons political or safety. ${ }^{\mathrm{ix}}$ Yet another pastor of the Truth Baptist Church, Connecticut urged Christians to avoid Muslims because the Commandments of Islam and the Prophet lack clarity in theory and practice. ${ }^{\mathrm{x}}$ A similar antagonistic view is shared by Rev. Rod Parsley, in his book, "Silent No More" (2005) that one of the purposes for founding America was 
to destroy Islam, which is false and anti-Christ. The Rev. called Islam as "anti-Christ religion". He also went so far to say that the Prophet of Islam received revelations not from God but from demons. ${ }^{x i}$ Apart from that, a significant amount of anti-Islamic literature was produced in post 9/11 decade to prove that Islam is anti-Semitic. AntiPluralistic religion. Some of the anti-Islam scholars focused on "sword verses" taken from Qur'an (e.g. 9:5) Allah commands, "And when the sacred months are over, kill the disbelievers wherever you may meet them, and take them captive, and besiege them, and lie in wait for them in every suitable ambush" This verse is interpreted in a way to prove that religious pluralism doesn't exist in Islam, therefore Muslims can't integrate in a nonIslamic environment are aimed at developing theories of hate and legitimizing prejudice against Muslims.

One of the reasons for mistrust between Islam and the West Fethullah states, "Reducing religion to a harsh political ideology and a mass ideology of independence has erected walls between Islam and the West" xii Human Rights Watch Report (2014), states that ISIS justifies it's taking the lives of people of the other faiths and by keeping them in the state of fear (particularly Yazidis and Christians) in the lands that it took over, such as Mosul. The so-called Islamic State has argued that their acts are in accordance with Islamic Law ${ }^{\text {xiii }}$. What kind of community is considered desirable in Islam?

The Shari'a means "the way of water" like water cleanses, nurtures growth and helps to develop into human beings, and towards inter-human relations as trustees of Allah. ${ }^{\text {xiv }}$ This is the kind of healthy society that Islam wants to create and nurture. The purpose of Sharia is harmonious progress, total care of society and not injecting the hurdle, disharmony, and disorder.

While examining the aim of Sharia Abu Hamid, al-Ghazali (d.505/1111), a great jurist comments, "The very objective of Shari' $a$ is to promote the welfare of the people which lies in safeguarding their faith, life, intellect, posterity, and wealth. Whatever ensures the safeguarding of these five serve the public interest and is desirable." ${ }_{\mathrm{xv}}$ Ibn Qayyim, al-Jawziyya's (d.751/1350) remark also endorses the instance of Imam alGhazali on the purpose of Shari'a, and comments "The basis of Shari' $a$ is wisdom and welfare of the people in this world as well as the hereafter with complete justice, mercy, 
well- being and wisdom. Anything that moves people from justice to oppression, from mercy to harshness, from welfare to misery and from wisdom to folly, has nothing to do with Shari'a." xvi

\section{Theological Discussions and Understanding of the Verse (2:256)}

The historical background of this verse has significance in theological discussions and its jurisprudential and legal interpretations. The Quranic saying about no compulsion in religion $(2: 256)$, often is not entirely clear to the people of West. Esposito suggests that "Like all scriptures, Islamic sacred text must be read within the social and political contexts in which they were revealed. It is not surprising that the Quran, like the Hebrew Scriptures or Old Testament, has verses that address fighting and the conduct of war." "xvii Is this (2:256) verse abrogated? According to Imam al Qurtabi, there are six opinions in this regard, according to some scholars the verse (2:256) is abrogated $^{\text {xviii }}$ and the passage was abrogated by later Quranic verses ( e.g. 9:73), "O Prophet! Struggle against the unbelievers and hypocrites and be harsh with them" and 9:5 "kill the unbelievers wherever you find them". In the verse (9:73), Allah has specifically enjoined the Prophet (PBUH) to fight against non-believers of Makkah of that time as they were constantly plotting against Islam. Is it justifiable for every Muslim to take up arm against non-Muslims of today? The expressions in the Qur'an (9: 5) are intended towards people who use violence and who utterly fail to abide by any rule/ law and only understand the rhetoric of war. This verse also aims at removing the violent, polytheist outlaws from Makkah and Medina and therefore was significant for the security of the center of Islam. Killing and conquering lands through war has never been the goal of Islam. Therefore, the Qur'an (8:61) says, "But if they incline to peace, incline thou to it as well, and the place thy trust in Allah". Ali Unal comments on the Qura'nic verse 9:6 and says "Muslims should also give asylum to those who seek it and, without harming in any way the wealth or persons of asylum seekers, convey them to a place of safety". xix

Does abrogation of this verse mean that compulsion in religion is justified? If yes, there would be violation of many fundamental Qura'nic principles and verses, such as Allah says (10:99), "Will you then compel mankind, against their will, to believe!", and 
(13:40), "Your duty is to make (the message) reach them. It is for us to call them to account." and (18:29) "Say, the truth is from your Lord. Let him who will, believe and let him who will reject (it)." and (76:3) "We showed him the way, whether he be grateful or ungrateful (rest on his will). "The meaning of this passage should be understood in the context. Islam visualizes universal peace and accepts the reality of human diversity, ensures peace and only rarely needs warfare. As commended in the Qur'an, (2:191, 2:217). ${ }^{\mathrm{xx}}$ Therefore, abrogation of the verse does not justify compulsion in religion.

Is this statement only symbolic? Is this phrase "no compulsion.." a narrative (Akhbar), or an imperative (Nahi)? Abu Bakr Jassas, al-Alusi, Ibn Ujaiba, Ibn Ashur, Sayyid Qutb wrote in the exegesis of this Quranic verse (2:256) that it is imperative for Muslims should avoid this seemingly descriptive phrase as an imperative statement in nature. Some other commentators like Abu al-Saud, Baydawi, al- Tantawi, also mentioned the opinions of scholars that it is an imperative statement. There have been many theological debates on this issue. Early commentators of the Qur'an has provided the theoretical and historical background for the revelation of the verse. This verse was God's answer to concerning Ansar of Medina who tried to compel their children to enter into Islam. ${ }^{x x i}$

In the early centuries of Islamic rule, the spread of the faith was affected rather by persuasion and inducement than force. The rate and scale of voluntary conversion to Islam are difficult to assess from available evidence, and some scholars have argued that as late as the Crusades, non-Muslims still constituted a majority of the population and large numbers of Christians, Jews, and Zoroastrians adopted the religion of Muslims and became part of Islamic society. ${ }^{x x i i}$ In a verse already quoted from the Qur'an that "there is no constraint in religion," which was interpreted to mean that people cannot or should not be forced to change their religions. So for Christians and Jews under Muslim rule, the question of forced conversion and therefore of martyrdom rarely arose. For the Muslims themselves, it did not arise until centuries later. .xiii $^{\text {. }}$

\section{Arguments for the Verse}

The freedom of choice in Islam is the basic ingredient of conversion, therefore, conversion by force, coercion, and interference makes it null and void to the subject 
concerned, and a prosecutable crime for the preacher. Muhammad Asad clarifies that, "The term din denotes both the contents of and compliance with amorally binding law; consequently, it signifies 'religion 'in the widest sense of this term, extending over all that pertains to its doctrinal contents and their practical implications as well as man's attitude towards the object of his worship........ On the strength of above categorical prohibitions of coercion (ikrâh) in anything that pertains to religion, all Islamic Jurists (fuqaha), without any exception, hold that forcible conversion is under all circumstances null and void and that any attempt at coercing a non-believer to accept the faith of Islam is a grievous sin, a verdict which disposes of the widespread fallacy that Islam places before the nonbelievers the alternative of "conversion or sword". xxiv

What was the importance of the context and therefore the meaning of the revealed texts then and now? How are these texts read today? Does context really matter? Why the verse (2:256) and (9:5) have been given many meanings general and specific in a variety of contexts. These kinds of confusions can occur if certain passages from the Old and New Testaments are quoted in the same way. Allah says (Qur'an, 2:256) "There is no compulsion in religion. Verily, the right path has become distinct from the wrong path." While explaining this, Ibn-e- Kathir writes, "Do not force anyone to become a Muslim, for Islam is plain and clear and its proofs and evidence are plain and clear. Therefore, there is no need to force anyone to embrace Islam". ${ }^{x v}$ Tantawi (d.2010), a Grand Mufti of Jamia Al-Azhar, Egypt comments in the same relevance, "Verily there is no compulsion and coercion in the matters of doctrines and religions". ${ }^{x v i} \mathrm{He}$ added that

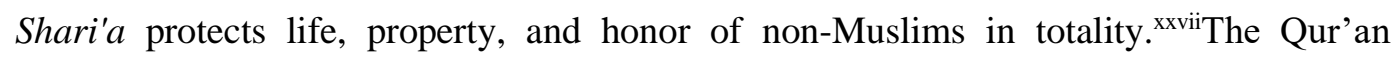
explicitly states "no compulsion in religion" but some scholars in the West as Bernard Lewis show reluctance on this and writes that "(This verse 2:256) a much quoted verse in the Quran and this was generally interpreted by Muslim Jurists and rulers to authorize a limited measure of tolerance for certain specified non-Islamic religious beliefs, without of course in any way questioning or compromising on the primary importance of Islam and the supremacy of Muslims." $x x v i i i$

According to Abû Hanîfa, al- Shâfî and Ibn Qudâmah, if a dhimmî or a musta'min is forced to accept Islam, the latter's acceptance of Islam is invalid until he 
remains a Muslim willingly after the coercive force has stopped. if a person was forcibly converted to Islam and later reverted to his former religion, he has not considered an apostate and may not be killed. Occasional exceptions were made to the rule that the penalty for apostasy was death. A famous case was that of Maimonides, who were forcibly converted to Islam in his birthplace in Spain and reverted to Judaism when he was able to escape to the east. One day, while at the height of his power and fame in Cairo, he was recognized by a Muslim fellow countryman who knew of his earlier conversion and denounced him as an apostate from Islam, demanding the penalty of death. Fortunately for Maimonides, the case was heard by the Qadi al-Fadil, his friend, and patron. The Qadi ruled that since Maimonides' conversion to Islam in Cordova had been obtained by force, it was not legally or religiously valid, and his reversion to Judaism did not, therefore, constitute apostasy. ${ }^{\text {xxix }}$

Muhammad Asad writes, "Obviously in the light of the Quranic principle, [There shall be no compulsion in religion] the religious commandments of Islam can't be binding upon non-Muslims." $x x x$ "No compulsion in religion" was not limited to freedom of individuals to choose their own religion but autonomy in all their internal affairs. During the Ottoman Empire non-Muslims had their own jurisprudential courts for cases which were held among themselves. ${ }^{\text {xxi }}$ "Verse 2:256, was revealed in the context of Muslim relations with the outside world, i.e., the relations between Islam and the other scriptural religions. ${ }^{\text {xxii }}$ "Compulsion in matter of religion breeds hypocrisy, an attitude which God detests most. Only inner mental attitudes matter in moral affairs, so meritorious acts can't be enforced. As the Prophet said: "Religion is sincerity". ${ }^{x x x i i i}$ The Quranic commandment to be tolerant applies to Muslims as it applies to non-Muslims. ${ }^{\text {xxiv }}$ Murad Hofmann comments that "It is unthinkable that God should command Muslims to protect the intellectual and moral dignity of non-Muslims and their freedom of conscience (2:256), and yet want to see Muslims subjected to compulsion."xxxv

\section{History of Tolerance and Intolerance}

Any proofs that people accepted Islam out of their own free-will- What about spread of Islam to other countries. In most parts of Islamic history, there are no 
evidences of forced conversion of people, because it is an offence towards Allah and the sanctity of the Godly choice of wright and wrong granted to men. More Muslims live in Indonesia than in any other Islamic country. Islam is the most dominant on the main islands of Sumatra and Java. Which is one of the largest Islamic countries in the world. After 1100, Islam brought about by Muslim missionaries and which soon spread to the main Island of Sumatra and Java. Muslim merchants and missionaries from South India came to the northern tip of Sumatra and planted Islam, from where it spread to the eastern tip of Java. In 1292 Marco Polo on visit to Sumatra observed that there were pagans on the Island, but native population have been converted to "the Law of Mahomet" by the Saracen merchants who frequently visit the ports. By 1400, the Shafi'i school of Islamic Law brought about by Indian Muslims from Delhi still prevails. At about the same time, Islam has strengthen by the rulers of Malacca Megat Iskandrshah. By the early 1500s the rapid spread of Islam in Indonesia aided in the monopolization of trade and management by Muslim merchant ${ }^{\mathrm{xxxvi}}$

In few of the victorious historical phases of Muslims, we find a Church being changed in to a Mosque, as the Hagia Sophia in Turkey, and the reverse also happened often when Christianity triumphed, e.g. the Grand Masjid of Cordova in Spain was changed into a Church.

In Islam, the general practice is one set up by 'Umar (r.a), who on the conquest of Jerusalem, commended the Church of the Holy Sepulchre to be respected and preserved as a church. Otherwise, many places of Christian worship in the Islamic world that later became mosques which were those deserted by Christian worshipers, somewhat like what today we see in some cities of Europe and America. ${ }^{\text {xxxvii }}$ Khaled Abou El Fadl refused the accusation of maltreatment of minorities of other faiths in the Islamic States and says that the Egyptians welcomed the rule of Muslims and rejoiced the fall of Byzantine forces. The Jews escaped to Muslim territories when inquisition became dominant in Spain. The Jews took refuge and set up financial institutions in Muslim countries when the Inquisition came to Venice. Great scholars like Maimonides and others were able to write in safety in Muslim Countries. Muslims living in Europe were forced to leave whereas there were no such problems with Christians in Muslim lands. Jews lived in 
Muslim Countries until 1967 war and then migrated to Israel. ${ }^{\text {xxxviii }}$

Bernard Lewis writes that "Two stereotypes dominate most of what has been written on tolerance and intolerance in the Islamic world. The first depicts a fanatical warrior, an Arab horseman riding out the desert with a sword in one hand and the Qur'an in the other, offering his victims the choice between the two. This picture, made famous by Edward Gibbon in his Decline and fall of the Roman Empire, is not only false but impossible......... The other image, almost equally preposterous, is that of an interfaith, interracial utopia, in which men and women belonging to different races, professing different creeds, lived side by side in a golden age of unbroken harmony, enjoying equality of rights and of opportunities, and toiling together for the advancement of civilization". ${ }^{x x i x}$ Muslim majority countries, even Saudi Arabia, Iran, Turkey and others, there are Sikhs, Hindus, Christians, Jews etc. who have been residing there for centuries. In case if there was forced conversion, then in the last fourteen centuries they would have all become Muslims. ${ }^{x}$ Such cases were few and far in which people were forced to accept Islam as it is reported by the western writers that during the Turkic dynasty of the Seljuqs, around 1100, non-Muslim boys were chosen from tribes converted to Islam and they were made slaves of the rulers and staffed for military and administrative elites. ${ }^{\text {xli }}$

Uni Avnery, ex-member of the Israeli parliament, raised a question in the response to Pope's statement about Islam. How did the Muslim rulers behave for more than a thousand years, when they had the power to "spread the faith by the sword"? And replied that, well they just did not. Uni Avnery writes that "For the many centuries, the Muslims ruled Greece. Did the Greeks become Muslim? Did anyone even try to Islamize them? On the contrary, Christian Greeks held the highest positions in the Ottoman administration. The Bulgarian, Serbs, Romanians, Hungarians and other European nations lived at one time or another under the Ottoman rule and clung to their Christian faith. Nobody compelled them to become Muslim and all of them remained devoutly Christian........400 years into the occupation of Palestine by the Muslims, Christians were still the majority in the country"43 $\mathrm{He}$ further writes that there is no evidence what so ever of any attempt to impose Islam on the Jews.....In Muslim Spain, Jews were ministers, poets, scientists. In Muslim Toledo, Christian, Jewish and Muslim scholars worked 
together and translated the ancient Greek philosophical and scientific texts. That was, indeed, the Golden Age. How would this have been possible, had the Prophet decreed the "spreading of the faith by the sword... The story about "spreading the faith by the sword" is an evil legend"xlii

Thomas Petriano admits and writes that "More recently, the kindness of many 'righteous Muslims', has been recognized by the Israeli government at the Holocaust Memorial of Yad Vashem in Jerusalem. It is a little-known fact that among the 20,000 men and women who have been recognized by the Israeli government as 'Righteous Among the Nations' because of their heroic deed of kindness in helping Jews during the Holocaust, 70 are Muslims. Their names are preserved along The Avenue of the Righteous at Yad Vashem. Echoing the words of the Qur'an, 5:32- 'and if anyone saved a life, it would be as if he saved the whole humanity' -there is a verse from the Jewish Mishnah inscribed at Yad Vashem that states, "Whosoever saves a single life, saves an entire universe." (Mishnah Sanhedrin 4:5). ${ }^{\text {xiii }}$

Muslim early jurists have rejected the validity of forcible conversion to Islam. The Arab governor of Lebanon had crushed a rebellion among the Christians, and alAwza'i, a Syrian Arab jurist accused him of acting with discriminate harshness. The governor, he said, had expelled dhimmis from Mount Lebanon who had had no part in the rebellion: "You killed some, and sent others back to their villages. How can you punish for the sins of the few and deprive them of their homes and property, when God has decreed that 'none shall bear another's burden' (Qur'an 6: 164). The best counsel to observe and follow is that of the Prophet........who said, 'If anyone oppresses a mu'ahad and burdens him beyond his capacity, then I myself will be his accuser [on the Day of Judgment].' xliv In the period of the Crusades, a jurist ruled on the question of whether a Muslim ruler may deport his dhimmi subject. The answer was that he may, but only if there is a good reason, whether for their own protection or in the interest of Muslim security. ${ }^{x l v}$ The negative opinion of Islam is not a new thing. It is true that during the nineteenth century there were some who made an attempt to give a more informed account, so that when Carlyle wrote Heroes and Hero- Worship, he could choose for his example of the Hero as Prophet, Chose not Isaiah or Jeremiah, nor even John the Baptist, 
but Muhammad..$^{x l v i}$

It is reflected from Qur'an and Prophetic traditions that there is no compulsion in religion and it is prohibited to force all others to become Muslims. Forced conversion is an unIslamic act and there is no justification for that whatsoever. Muslims are not enjoined to spread Islam by force but they are enjoined to invite people with wisdom, beautiful and the most courteous ways (Qur'an 16:125). Muslims have to recognize the decision of people who don't accept Islam, no social, or political pressure may be put on them to change their religion. There are texts in all religions to which one can point if one wants to impute blame for violence but everything depends on how those texts are perceived, read, understood and interpreted. Faith is intrinsic to the soul and how can the sheer force influence the soul?

\section{CONCLUSION REMARKS}

Qur'an disallowed to preach Islam by any forceful mean. Islam doesn't and therefore, should not coerce anyone to change their dogma. In fact it creates an environment where all are free to practice their religions. Religious ideology is not necessarily the driving force for extremism and violent acts against humanity and rather cannot be legally and ideologically justified in the name of religion. There is a huge difference between ideologically motivated and politically driven motives such as to provoke the West against the Muslim World. Why are people joining extremist? How do we protect our youth from being brainwashed by the ideology of extremists? It seems that it is due to feeling of discrimination. There is mutual obligation on believers of all faiths not to give chance terrorism to prevail. Muslim leaders should think of how can they enhances peaceful image of Islam for? At present in most of the cases Jihad has been instrumentalized for political control and conversion. There are examples of forced conversion in human history. Muslims individually have also committed the mistake to force others to accept Islam but Islam cannot be blamed for that. Faith should be heartfelt and Iman cannot be valid until it is accepted by heart not under any pressure, forced conversion cannot take root in the heart of people therefore this kind of efforts will be considered null and void according to all schools of jurisprudence. Indeed, there are sweeping generalization on the question of religious compulsion in Islam. How should 
one approach the Qur'an regarding 2:256? It is in effect on exercise in confirming one's preference and tends towards "cherry-picking" the quotes like these ones. When there is no compulsion in Islam why did Muslims participate in Jihad? Purpose of Jihad was/is not to force others to accept Islam but to defend themselves and to remove the obstacles from the way. The above discussion shows that 'no compulsion in faith' is an established Islamic rule that was practiced by the Muslims during their period of rise and power. Islamic tradition of no coercion in faith is essence of religious pluralism. The passage (no compulsion...) from the Qur'an commonly referred to the discussions about freedom of religious choice "There is no compulsion in religion"(la ikrah fi'd-din) mean to different people. Muslim books of jurisprudence devote considerable attention to the issue of religious compulsion and carnage. Both Quran and the Prophetic traditions strongly emphasize on the sanctity of covenants, and to honour the lives and belongings of people of other faiths, called mu'ahad, with whom a treaty ('ahd) has been concluded.

\section{REFERENCES}

Abu Abdullah, Muhammad b. Abdullah. (NG). Mishkatul Masabeeh .Kitabul Adab, Babul Shafqat wa Rahmah. Lahore: Maktaba Rahmania. p.439

Al- Qarshi, Yahya b. Adam.(1979). Kitab al- Khiraj. Beirut: Darul Maarifa p.76 .

Abu Yusuf, Ya'qub Ibn Ibrahim. (1979). Kitab al- Kharaj. Beirut: Darul Marifa. p.125

Sahih Al- Bukhari. Kitab no 49 Bab no.17 Hadith no 2554

Shaykh Muhammad al-Yaqoubi.(2015). Refuting ISIS US: Sacred Knowledge p.10

Robert A. Burns. (2011). Christianity, Islam, and the West. New York: University Press of America p.108

Shari'a in the West. (2010). edi. by Rex Ahdar and Nicholas Aroney New York: Oxford University Press. Pp.194-204

Ahmad Gunny. Book Review on 'Islam in the Eyes of the West: Images and Realities in an Age of Terror' ed. Tareq Y. Ismael and Andrew Rippin . Abingdon: Routledge, 2010 published in Journal of Islamic Studies ,Oxford Center for Islamic Studies Volume23, issue 2 May 2012 p.276-277, http://jis.oxfordjournals.org/

Ahmad Gunny. Book Review on 'Islam in the Eyes of the West: Images and Realities in an Age of Terror' ed. Tareq Y. Ismael and Andrew Rippin . Abingdon: Routledge, 2010 published in Journal of Islamic Studies, Oxford Center for Islamic Studies Volume23, issue 2 May 2012 p.276-277, http://jis.oxfordjournals.org/

Ahmad Gunny. Book Review on 'Islam in the Eyes of the West: Images and Realities in an Age of Terror' ed. Tareq Y. Ismael and Andrew Rippin . Abingdon: Routledge, 2010 published in Journal of Islamic Studies, Oxford Center for Islamic Studies Volume23, issue 2 May 2012 p.276-277, http://jis.oxfordjournals.org/

M. Fethullah Gulen .(2006 ). Essays, Perspectives, Opinions. New Jersey: The Light p. 36

http://www.hrw.org/news/2014/07/19/iraq-isis-abducting-killing-expelling-minorities Reterived April 17,2015 
John Bowker (2000).What Muslims believe .Boston: Oneworld Publication p.10 Al- Ghazali (1987). Al Mustasfa Min IImul Usul .Karachi: Idaratul Quran, Vol. 1. p140.

Ibn Al Qayyim al-Jawziyya, Muhammaad Ibn Abi Bakr.(1977). Alamul Mwqqiein An Rabbil Alamin. Beirut: Darul Fikr, Vol. 3, p. 4.

Esposito, John L. (2002). What Everyone Needs to Know about Islam. New York: Oxford University Press p.119

al Qurtabi, Muhammad b. Ahmed b. Abi Bkr.(2006). Al-Jami li Ahkam al Quran ed. Abdullah b. Abdul Muhsin al- Turki Beirut: Mu'wassasa al-Resalah Voi. 4, p.280.

Ali Unal.(2006).The Quran with annotated Interpretation. New Jersey Pp.1469-1470 Ali Unal.(2006).The Quran with annotated Interpretation. New Jersey Pp.1470-1471 Jalal al Din al-Mahalli and Jalal al-Din Suyuti. (2007). Tafsir al-Jalalayn. Translated by Feras Hamza Jordan: Royal Aal-al-Bayt Institute for Islamic Thought p.47

Bernard Lewis. (1984). The Jews of Islam New Jersey: Princeton University Press p.17 Bernard Lewis. (1984). The Jews of Islam New Jersey: Princeton University Press p.82 Muhammad Asad. (1984). The Message of the Qur'ân: translation and explanation. Gibralter: Dar al-Andalus, Pp.57-58.

Ibn-e- Kathir, Abu Al- Fida Ismail. (2003).Tafseer Ibn-e-Kathir. Lahore: Darussalam, Vol. 2, p. 30

Tantawi, Syed Muhamad. (1997). Adab alhiwar Fil Islam Cairo, Dar Al Nahdah p. 56.

Tantawi, Syed Muhamad. (1997). Adab alhiwar Fil Islam Cairo, Dar Al Nahdah p. 58.

Lewis, Bernard (2002). What Went Wrong? Western Impact and Middle Eastern Response. New York: Oxford University Press. P. 113

Bernard Lewis. (1984). The Jews of Islam New Jersey: Princeton University Press p.100

Muhammad Asad. (1985). The Principles of State and Government in Islam Gibraltar: Dar Al-Andalus p.73

Mustafa Ruzgar. (2005). Islam and the Deep Religious Pluralism in Deep Religious Pluralism, ed. David Ray Griffin Louisville. Kentucky: Westminster John Knox Press. p.159

Murad Hofmann (1999). Islam the Alternative Maryland: Amana publication Pp.65-66

Murad Hofmann (1999). Islam the Alternative Maryland: Amana publication P.66

Murad Hofmann (1999). Islam the Alternative Maryland: Amana publication p. 67

Murad Hofmann (1999). Islam the Alternative Maryland: Amana publication p.67

George W. Braswell, Jr. (1996). Islam: Its Prophet, People, Politics and Power. Nashville, Tennessee: Broadman \& Holman Publishers p.37

Seyyed Hossein Nasr. (2004).The Heart of Islam: Enduring Values for Humanity. New York: Harper SanFrancisco p.52

Khaled Abou El Fadl. (2006). the Search for Beauty in Islam. New York: Rowman \& Littlefield Publisher p.3

Bernard Lewis. (1984). The Jews of Islam New Jersey: Princeton University Press p.3 John Bowker. (2000).What Muslims believe. Boston: Oneworld Publication p.6

Thomas W. Simons. (2003). Islam in a Globalizing World. California: Standford University Press p.11Uni Avnery, (2006).Muhammad's Sword see http://zope.gushshalom.org/home/en/channels/avnery/1159094813/ retrieved 22-2-2016

Thomas W. Simons. (2003). Islam in a Globalizing World. California: Standford University Press p.11 Uni Avnery, (2006).Muhammad's Sword see http://zope.gushshalom.org/home/en/channels/avnery/1159094813/ retrieved 22-2-2016 
Thomas Petriano, Four Cups of Tea in The Fountain Issue No 105, May-June 2015, p.44 It is found on the Yad Vashem website. The stories of many of these courageous men and women can be found at the Yad Vashem website and also in Robert Saloff's book, Among the Righteous:Lost Stories from the Holocaust's Long Reach into Arab Lands."

Bernard Lewis. (1984). The Jews of Islam New Jersey: Princeton University Press Pp. 41-42

Bernard Lewis. (1984). The Jews of Islam New Jersey: Princeton University Press p. 43

Bowker. (2000).What Muslims believe. Boston: Oneworld Publication p.3 